\title{
Haploidentical transplantation in patients with multiple myeloma making use of natural killer cell alloreactive donors
}

\author{
Catharina Van Elssen ${ }^{1} \cdot$ Gwendolyn van Gorkom ${ }^{1}$ (D) $\cdot$ Christine Voorter $^{2} \cdot$ Peter von dem Borne $^{3} \cdot$ Ellen Meijer $^{4}$. \\ Lotte Wieten $^{2} \cdot$ Gerard Bos $^{1}$
}

Received: 30 April 2020 / Accepted: 15 October 2020 / Published online: 28 October 2020

(C) The Author(s) 2020

\begin{abstract}
Disease relapse is an important problem after allogeneic stem cell transplantations in multiple myeloma (MM). To test the hypothesis that natural killer (NK) cell alloreactivity in the setting of a haploidentical stem cell transplantation (haploSCT) can reduce the risk of myeloma relapse, we performed a small prospective phase 2 study in which we transplanted poor-risk MM patients using a killer cell immunoglobulin-like receptor (KIR)-ligand mismatched haploidentical donor. Patients received bone marrow grafts after reduced-intensity conditioning, with post-transplantation cyclophosphamide (PTCY) graft-versus-hostdisease (GVHD) prophylaxis. The primary endpoint was 1.5-year progression-free survival (PFS); stopping rules were installed in case interim results made a benefit of 50\% PFS at 1.5 years unlikely. After inclusion of 12 patients, of which 9 were evaluable for the primary endpoint, all patients relapsed within a median time of 90 days. All except 1 patient showed engraftment, with a median time to neutrophil recovery of 18 (12-30) days. The study was prematurely terminated based on the predefined stopping rules after the inclusion of 12 patients. With this small study, we show that in chemo-resistant myeloma patients, NK cell KIRmismatch is not superior to conventional alloSCT. This strategy, however, can serve as a platform for new treatment concepts. Clinical Trial Registry: NCT02519114
\end{abstract}

Keywords Stem cell transplantation $\cdot$ Multiple myeloma $\cdot$ NK cells

\section{Introduction}

In recent years, the use of haploidentical donor cells for the treatment of hematological malignancies has been increasing and has proven effective and safe, especially with the use of PTCY $[1,2]$. There is limited documentation about haploSCT in MM, but small retrospective studies show this is feasible with relatively low non-relapse mortality (NRM). Results in terms of PFS are however similar to HLA-identical SCT

Catharina Van Elssen

janine.van.elssen@mumc.nl

1 Internal Medicine, Division of Hematology, Maastricht University Medical Center, P. Debyelaan 25, 6229 HX, Maastricht, Netherlands

2 Department of Transplantation Immunology, Maastricht University Medical Center, Maastricht, Netherlands

3 Department of Hematology, Leiden University Medical Center, Leiden, Netherlands

4 Department of Hematology, Amsterdam University Medical Center, Location VUMC, Cancer Center, Amsterdam, Netherlands
[3-5]. HaploSCT offers an attractive opportunity to introduce natural killer (NK) cell alloreactivity based on a KIR-ligand mismatch. In myeloid malignancies, this NK alloreactivity, in the context of a T cell deplete haploSCT, leads to a decreased relapse rate and improved survival without causing GVHD [6-8]. Unlike in T cell-depleted haploSCT, the benefit of NK cell alloreactivity in T cell replete haploidentical SCT is less clear and the limited number of small-sized studies concerning this effect is not conclusive [9-12]. The differences concerning NK cell alloreactivity in these studies might be due to the disease heterogeneity of the included patients and differences in the conditioning regimen and stem cell source. Some studies point towards a better outcome when bone marrow stem cells were used compared to peripheral blood stem cells, which was shown to correlate with the T cell content of the graft that is higher in peripheral blood stem cell products [12]. This correlation is in line with reports on the inhibitory effect of $\mathrm{T}$ cells on the development of alloreactive NK cells [13].

There is much evidence to support the role of NK cells in fighting MM [14-17]. It has been proven that therapeutic 
interventions like lenalidomide and elotuzumab result in increased NK cell-mediated anti-myeloma responses [18, 19]. In preclinical studies performed by our research group, we show that NK cells are able to kill MM cells, and this killing is improved in the presence of NK alloreactivity [20, 21]. This was shown in vitro as well as in a humanized mouse model. Two small clinical studies also implicated a beneficial role for KIR-ligand mismatch in MM. In one study, the role of administration of alloreactive NK cells before autologous SCT was examined. High remission rates were observed, although they were short-lived [22]. In another study, the impact of KIRligand mismatch in a HLA-identical and mismatched SCT setting was investigated and showed that KIR-ligand mismatch in the graft-versus-host direction was protective for relapse [23].

The aim of this phase 2 study was to prospectively evaluate if KIR-ligand mismatched haploidentical bone marrow transplantation (BMT) with PTCY improves PFS in poor-risk MM patients.

\section{Methods}

\section{Patients}

In this prospective, single-arm, multicenter trial, we recruited poor-risk MM patients aged below 66 years with good clinical performance from hospitals in the Netherlands. Poor risk was defined as high-risk cytogenetics (del17p and/or $t(4 ; 14)$ and/ or $t(14 ; 16))$, or relapse within a year after autologous SCT, or relapse after three or more previous lines of therapy. Furthermore, patients had to be responsive to their last line of therapy, defined as at least partial response according to the International Myeloma Working Group consensus criteria [24]. Another prerequisite of enrolment was the permissiveness to NK alloreactivity and availability of a KIR-ligand mismatched haploidentical family donor. Patients were excluded if donor-specific HLA-antibodies were present.

\section{Donor selection}

All patients were transplanted with a KIR-ligand mismatched haploidentical family donor. The opportunity for KIR-ligand mismatched haploBMT was determined by Luminex sequence-specific oligonucleotide hybridization (SSO) typing for the three possible inhibitory KIR-ligands: HLA-C group 1 (ligands for KIR2DL2/3), HLA-C group 2 (ligands for KIR2DL1), and HLA-Bw4 including HLA-A harboring Bw4 motifs as ligands for KIR3DL1 (A*23, A*24, A*32).

In case of an opportunity for KIR-ligand mismatched haploBMT, a KIR-ligand mismatched haploidentical family donor was searched in the wide family tree of the patients. In case a probable KIR-ligand mismatched donor was identified by low resolution, a second blood sample was drawn from this potential donor for confirmation in high resolution, for KIR typing, by low-resolution Luminex SSO assay. Protein expression of the mismatched KIR was confirmed by immune phenotyping of the peripheral blood NK cells for KIR expression as described below.

\section{Immune phenotyping for KIRs during donor selection and NK cell reconstitution}

Peripheral blood mononuclear cells were isolated by gradient density centrifugation and stained with monoclonal antibodies with specificity for CD3 (SK7, BD), CD56 (B159, BD), NKG2A (Z199, Beckman Coulter), KIR2DL1 (143211, R\&D), KIR2DL2/3/S2 (DX27, Miltenyi Biotech), or KIR3DL1 (DX9, Miltenyi Biotech) followed by acquisition of the samples on a BD FACS Canto II machine. Acquired data were analyzed using the Diva software by gating on living CD3- CD56+ lymphocytes followed by analysis of the percentage of positive cells for the individual KIRs.

\section{Conditioning and transplant procedure}

Conditioning regimen consisted of cyclophosphamide 14.5 $\mathrm{mg} / \mathrm{kg}$ on day -6 and -5 , fludarabine $30 \mathrm{mg} / \mathrm{m}^{2}$ from day 6 to -2 and 200 cGY total body irradiation at day - 1 in all but one patient that received busulfan instead of cyclophosphamide pre-transplant. Donor bone marrow cells were infused on day 0 . Bone marrow cells were used in all but one patient, since they are preferred over peripheral blood stem cells because of a lower risk of acute and chronic GVHD [25, 26].

\section{GVHD prophylaxis and supportive care}

GVHD prophylaxis consisted of cyclophosphamide $50 \mathrm{mg} / \mathrm{kg}$ at day +3 and +4 . Mycophenolate mofetil was used from day +5 to +35 . Tacrolimus $0.1 \mathrm{mg} / \mathrm{kg}$ was added to this combination from day +5 to +180 .

To prevent infections, patients received immunoglobulins $0.2 \mathrm{~g} / \mathrm{kg}$ once every 4 weeks from 1 week before conditioning until the immunosuppressive drugs were stopped. Antimicrobial prophylaxis furthermore consisted of cotrimoxazole and valaciclovir, and during neutropenia, ciprofloxacin and fluconazole were given as selective digestive decontamination.

\section{Study endpoints and statistical analysis}

The primary endpoint was PFS at 1.5 years. Since haploBMT is a demanding and costly treatment for the patients, we considered the effect that has to be realized by this procedure needed to be substantial and chose for the PFS goal of $50 \%$ 
in 1.5 years compared to around $25 \%$ with conventional alloSCT according to historical data.

To test this hypothesis, Simon's two-stage design was used. We hypothesized that the 1.5-year PFS will be $50 \%$ after haploBMT, while this is a maximum $25 \%$ in the hypothetical standard treatment group (conventional alloSCT according to historical data). To demonstrate this difference with a power of $80 \%$ and a type 1 error rate, alpha (one-sided) of $0.05 \%, 24$ patients were needed. If 1 or less of the first 9 patients experienced 1.5-year PFS, the relevant predefined positive effect was considered very unlikely and the study would be stopped.

Secondary endpoints were engraftment, bone marrow reconstitution, NK cell reconstitution and repertoire, GVHD, infections, and NRM.

To ensure safety, we build in decision rules to prematurely terminate the study if the NRM at 100 days exceeded a certain percentage that was calculated beforehand based on a modification of the standard $3+3$ scheme.

Analyses were performed as of April 2020. Pretransplantation patient characteristics were given as median and range for continuous variables and as frequency and proportion for categorical variables. PFS was analyzed using a Kaplan-Meier estimate. For NRM, relapse, and GVHD, a competing risk framework was used. The analysis was performed with the R software.

\section{Results and discussion}

In total, 12 poor-risk patients were included from 3 hospitals in the Netherlands from April 2016 to May 2018 with a follow-up until April 2020 and the median time to follow-up is 30.2 months (range 11.8-44.9 months). Pre-transplantation patient characteristics are described in Table 1 . They were all heavily pre-treated with both proteasome inhibition and immunomodulatory drugs;

Table 1 Patient characteristics

\begin{tabular}{ll}
\hline $\begin{array}{l}\text { Gender, } n(\%) \\
\text { Male }\end{array}$ & $10(91)$ \\
Female & $1(9)$ \\
Age, median in years (range) & $61(40-66)$ \\
Response to last therapy, $n(\%)$ & \\
PR & $5(45)$ \\
VGPR & $5(45)$ \\
CR & $1(9)$ \\
Previous lines of treatment, median (range) & $3(2-7)$ \\
Previous SCT, $n(\%)$ & \\
1x autologous & $8(73)$ \\
2x autologous & $3(27)$ \\
Allogeneic & $1(9)$ \\
\hline
\end{tabular}

none of the patients received antibody treatment before inclusion. One patient had known high-risk cytogenetics and three patients showed progression within 12 months after autologous SCT. We excluded one patient for further analysis due to disease progression just before BMT, since this was a predefined exclusion criterion. This patient, however, was transplanted because pre-transplant M-protein levels became available during conditioning therapy. KIR/HLA incompatibility of the different donors is described in Table 2.

\section{Clinical endpoints}

Of the 11 evaluable patients, 10 achieved primary engraftment $(91 \%)$, with a median time to neutrophil and platelet engraftment of 18 (12-30 days) and 30 (20-49 days) days, respectively. Grade 2-4 acute GVHD occurred in 2 of 11 patients (none grade 3-4) and chronic GVHD occurred in 4 of 11 patients. Two of the 11 patients died of treatment-related mortality $(18 \%)$ within the first year.

Of the 9 for the primary endpoint evaluable patients, all patients relapsed within 1 year (Fig. 1a). The median time to relapse was 90 days (range 30-360 days), and 8 of 9 patients had to eventually start anti-myeloma treatment. The median time for the next treatment was 186 days (range 40-330 days); two-thirds of the patients at first only biochemically relapsed without a need for treatment. Overall survival was $73 \%$ after 1 year and $52 \%$ after 2 years (Fig. 1b).

Noteworthy is one patient, who relapsed quickly after SCT with an increase of her involved free light chain, displayed a spontaneous decrease 60 days after BMT to pre-transplant levels (Fig. 2). During this period, no additional antimyeloma treatment was started. Only immune-suppressive treatment with mycophenolate mofetil was stopped at day + 35 , as per protocol. She did not require any treatment until 400 days after the stem cell transplantation. Interesting is also a second, heavily pre-treated patient that was already progressive at day 40 after SCT, but had a complete remission on daratumumab and has continuous bone marrow-proven remission more than 2 years after stopping this treatment.

\section{NK cell reconstruction}

At day 30, all of the 8 analyzed patients showed NK cell recovery, though with an immature phenotype $\left(\mathrm{NKG} 2 \mathrm{~A}^{+}\right.$, $\mathrm{KIR}^{-}$). At day 60 in both the peripheral blood and bone marrow, mature NK cells ( $\mathrm{KIR}^{+}$) could be identified (Fig. 3a-d). We have no data on the functionality of these cells.

\section{Discussion}

With this study, we tested the safety and the efficacy of a KIRmismatched haploidentical BMT in high risk MM patients. 
Table 2 Donor and recipient HLA typing and NK mismatch

\begin{tabular}{|c|c|c|c|c|c|c|}
\hline $\begin{array}{l}\text { Patient } \\
\text { NR. }\end{array}$ & $\begin{array}{l}\text { Patient HLA } \\
\text { present }\end{array}$ & $\begin{array}{l}\text { Patient HLA } \\
\text { absent }\end{array}$ & $\begin{array}{l}\text { Donor HLA } \\
\text { present }\end{array}$ & $\begin{array}{l}\text { Donor HLA } \\
\text { absent }\end{array}$ & Mismatch & $\begin{array}{l}\text { iKIR } \\
\text { mismatch }\end{array}$ \\
\hline P1 & $\mathrm{Bw} 4, \mathrm{C} 1$ & $\mathrm{C} 2$ & $\mathrm{Bw} 4, \mathrm{C} 1, \mathrm{C} 2$ & $X$ & $\mathrm{C} 2$ & 2DL1 \\
\hline $\mathrm{P} 2$ & $\mathrm{C} 2$ & Bw4, C1 & $\mathrm{C} 1, \mathrm{C} 2$ & Bw4 & $\mathrm{C} 1$ & 2DL2/2DL3 \\
\hline P3 & $\mathrm{Bw} 4, \mathrm{C} 2$ & $\mathrm{C} 1$ & $\mathrm{Bw} 4, \mathrm{C} 1, \mathrm{C} 2$ & $\mathrm{x}$ & $\mathrm{C} 1$ & 2DL2/2DL3 \\
\hline P4 & $\mathrm{C} 1, \mathrm{C} 2$ & Bw4 & $\mathrm{Bw} 4, \mathrm{C} 2$ & $\mathrm{C} 1$ & Bw4 & 3DL1 \\
\hline P5 & $\mathrm{Bw} 4, \mathrm{C} 1$ & $\mathrm{C} 2$ & $\mathrm{C} 1, \mathrm{C} 2$ & Bw4 & $\mathrm{C} 2$ & 2DL1 \\
\hline P6 & $\mathrm{C} 1$ & $\mathrm{Bw} 4, \mathrm{C} 2$ & $\mathrm{Bw} 4, \mathrm{C} 1, \mathrm{C} 2$ & $\mathrm{X}$ & $\mathrm{C} 2, \mathrm{Bw} 4$ & 2DL1/3DL1 \\
\hline P7 & $\mathrm{Bw} 4, \mathrm{C} 1$ & $\mathrm{C} 2$ & $\mathrm{Bw} 4, \mathrm{C} 1, \mathrm{C} 2$ & $\mathrm{X}$ & $\mathrm{C} 2$ & 2DL1 \\
\hline P8 & $\mathrm{C} 1, \mathrm{C} 2$ & Bw4 & $\mathrm{Bw} 4, \mathrm{C} 1, \mathrm{C} 2$ & $\mathrm{X}$ & Bw4 & 3DL1 \\
\hline P9 & $\mathrm{Bw} 4, \mathrm{C} 2$ & $\mathrm{C} 1$ & $\mathrm{Bw} 4, \mathrm{C} 1, \mathrm{C} 2$ & $X$ & $\mathrm{C} 1$ & 2DL2/2DL3 \\
\hline P10 & $\mathrm{C} 1$ & $\mathrm{C} 2, \mathrm{Bw} 4$ & $\mathrm{Bw} 4, \mathrm{C} 1, \mathrm{C} 2$ & $\mathrm{X}$ & $\mathrm{C} 2, \mathrm{Bw} 4$ & 2DL1/3DL1 \\
\hline P11 & $\mathrm{C} 1$ & $\mathrm{C} 2, \mathrm{Bw} 4$ & $\mathrm{Bw} 4, \mathrm{C} 1, \mathrm{C} 2$ & $X$ & $\mathrm{C} 2, \mathrm{Bw} 4$ & 2DL1/3DL1 \\
\hline P12 & $\mathrm{C} 1, \mathrm{Bw} 4$ & $\mathrm{C} 2$ & $\mathrm{Bw} 4, \mathrm{C} 1, \mathrm{C} 2$ & $\mathrm{x}$ & $\mathrm{C} 2$ & 2DL1 \\
\hline
\end{tabular}

HLA human leukocyte antigen, iKIR inhibitory killer cell immunoglobulin-like receptor
We observed that the treatment is safe since there was a high engraftment rate, low NRM (18\% at 1 year), and no unexpected adverse events. In the only two other retrospective studies concerning haploSCT with PTCY in MM where there was no selection on KIR-mismatch, comparable results were seen with respect to NRM (10-21\% in 1.5 to 2 years); however,
Fig. 1 Clinical outcomes after HaploBMT. a Probability of progression-free survival. b Overall survival

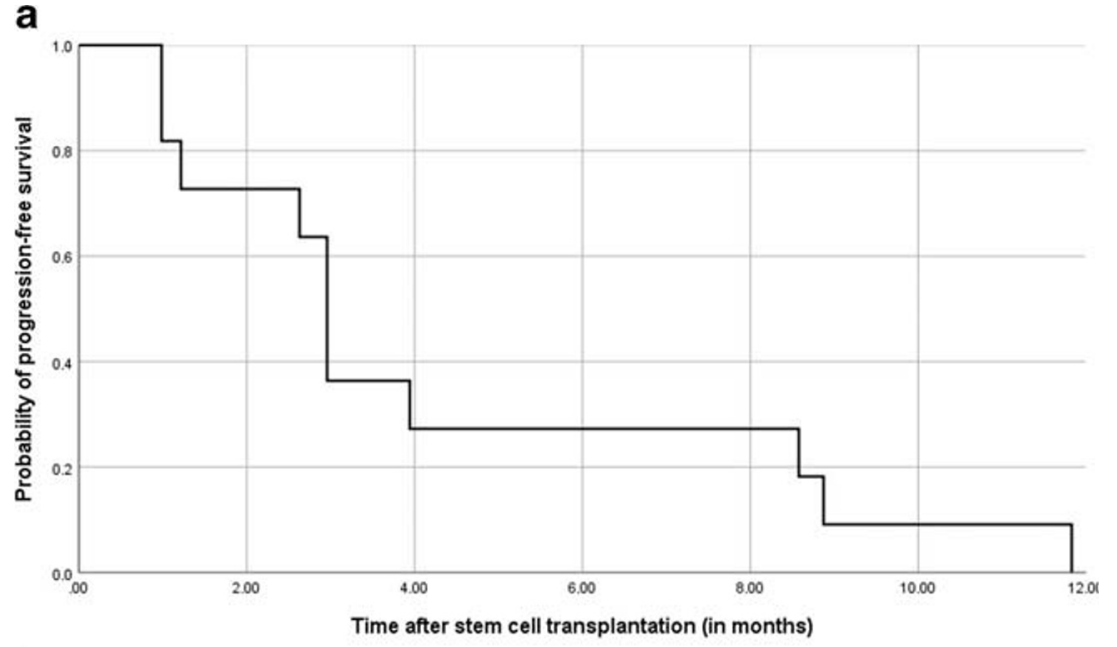

b

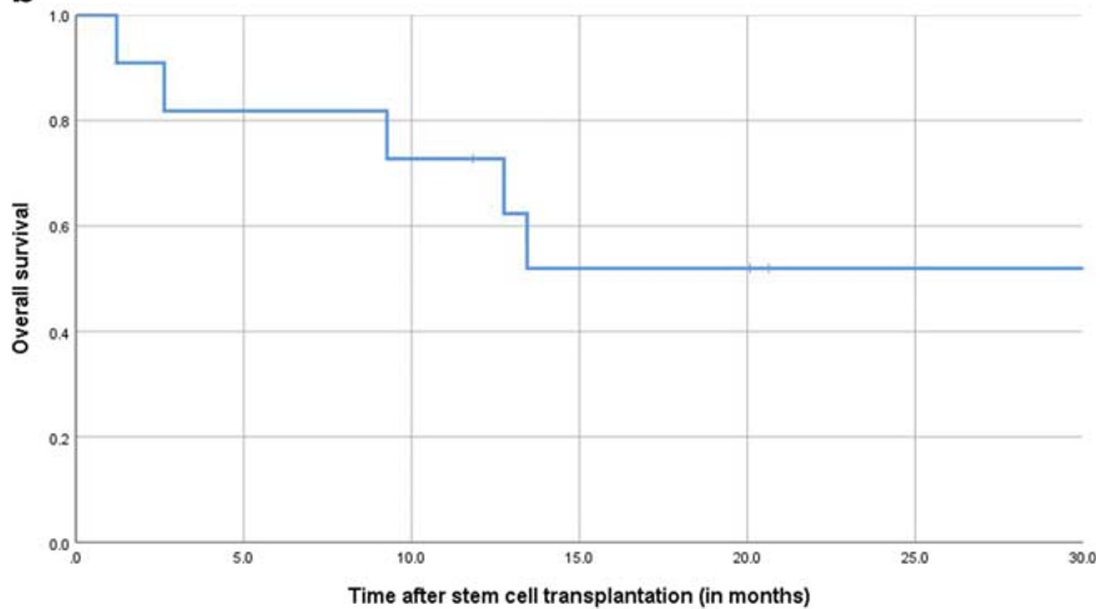




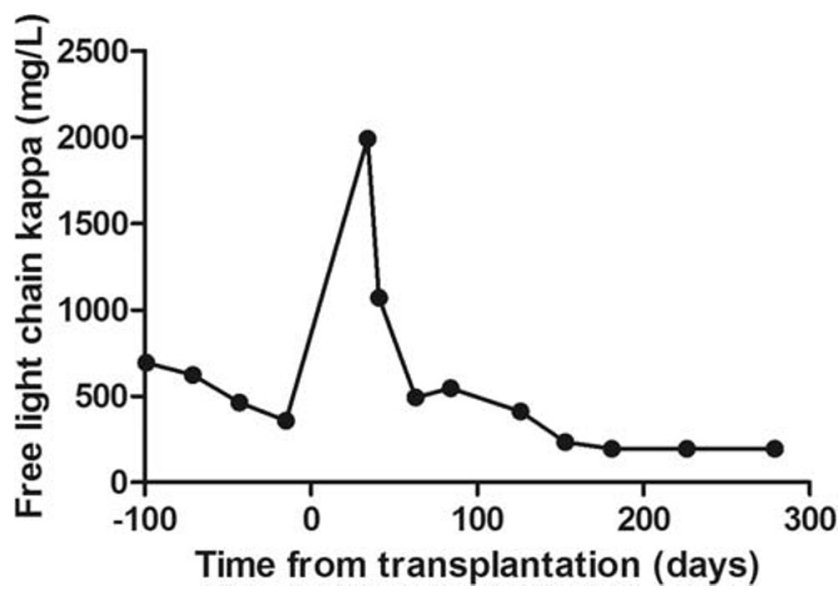

Fig. 2 Serum-free light-chain response after HaploBMT in one individual patient. Progression 30 days after transplantation and responsive thereafter without treatment

they had a slightly higher PFS (17-33\% in 1.5 to 2 years). In our small study, unfortunately, there is a 1.5 -year PFS of $0 \%$. This 1.5-year PFS seems lower than in conventional alloSCT studies. However, the study is underpowered to draw these

NKG2A

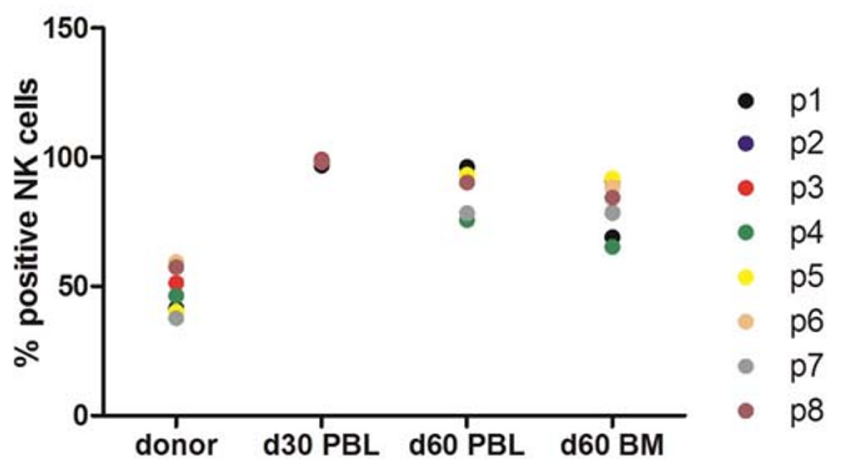

KIR2DL2/3

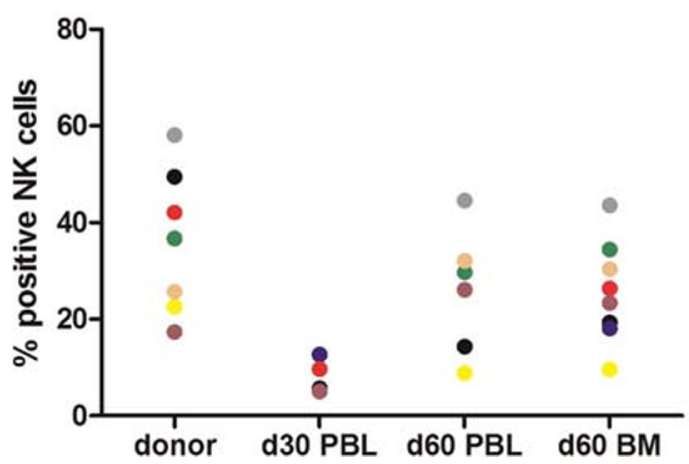

- $\mathrm{p} 1$

- $\mathrm{p} 2$

- $\mathrm{p3}$

- $\mathrm{p} 4$

- p5

- p6

- $\mathrm{p} 7$

- $p 8$

Fig. 3 a-d Assessment of NK cell phenotype after stem cell transplantation. Mononuclear cells were isolated from peripheral blood (PBL) or bone marrow (BM). To analyze KIR expression in the donor, PBL were harvested before from the donor before transplantation. To determine NK reconstitution upon transplantation, $\mathrm{PBL}$ or BM cells were isolated from the patient at $30(\mathrm{~d} 30)$ or $60(\mathrm{~d} 60)$ days after transplantation. conclusions, since the study was prematurely terminated due to the defined stopping rules based on a 1.5-year PFS of 50\%. Furthermore, this low PFS was also not unexpected since these were heavily pre-treated patients with very high-risk chemo-resistant myelomas. Though these patients showed a biochemical relapse, many of them did not require treatment for a long time after which is very unlikely for this fast progressive patient population. Even though it is difficult to draw conclusions in such a small, heterogenous group of patients, our results show that KIR-ligand mismatch in this patient category is not only harmful but also not more effective than nonmatched haploSCT or conventional alloSCT in curing MM [3, 4].

We hypothesize that the late reconstitution of functional mature NK cells is responsible for the lack of response. This has already been described in other patient groups after PTCY: within days after SCT, mature graft-derived NK cells appear, but they are rapidly eliminated by PTCY. Full reconstitution of a mature and functional NK cell population took 6 to 12 months [12]. The median time point of relapse in our patients occurred shortly after transplantation (around 3

KIR2DL1

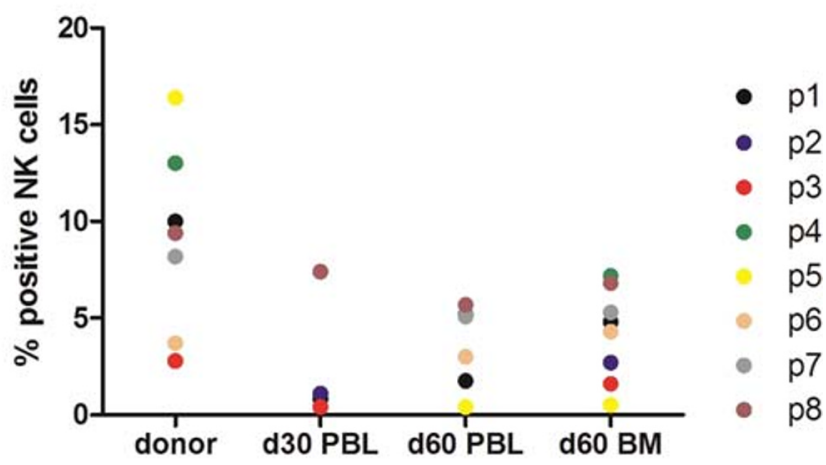

KIR3DL1

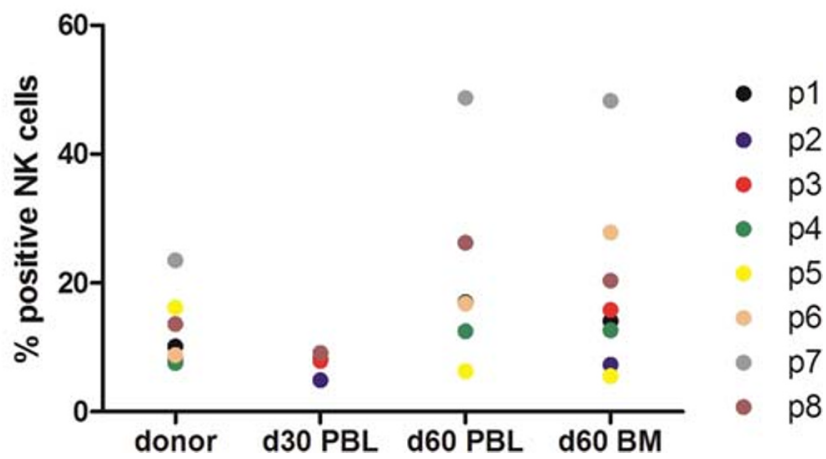

Isolated cells were stained and the percentage of CD3-CD56+ NK cells expressing KIR2DL1, KIR2DL2/3, KIR3DL1, or NKG2A was determined by flow cytometry. Patients and their donors are depicted as P1P8 in the legend and every dot represents one data point of cells analyzed at day $30(\mathrm{~d} 30)$ or day $60(\mathrm{~d} 60)$ after transplantation 
months). We detected that 30 days after haploBMSCT, most NK cells still had an immature phenotype without KIR expression and were not able to stop disease progression at this early stage after transplantation when myeloma cell load was still low. We hypothesize that the delayed NK cell reconstitution may be overruled by the infusion of mature, functional donor NK cells shortly after PTCY administration. In myeloid malignancies, this concept has already been used and seems successful in a small group of high-risk patients [27]. In this context, it may also be helpful to bridge the time to full NK cell restoration after the SCT with additional anti-MM therapy like elotuzumab or daratumumab, or to combine these two modalities. This concept is supported by the patient that showed a long-lasting complete response after temporary treatment with daratumumab. Another option would be to improve NK cell function and thereby increase the alloreactive effect by blocking antibodies, such as monalizumab, a novel checkpoint inhibitor against NKG2a [28].

In conclusion, in this study, we show that haploidentical BMT in MM patients is safe and feasible in terms of engraftment and late NK cell reconstitution. HaploBMT in MM forms a possible platform for future immunotherapeutic strategies in which the KIR-ligand mismatch might be beneficial. Though this study is limited in patient numbers, none of the patients showed a clinically relevant increase of PFS; therefore, we conclude that in the setting of haploBMT in combination with PTCY, however, a KIR mismatch probably is not clinically relevant.

Acknowledgments The authors thank the patients and their families for participating in the study.

Authorship contributions C.E., P.B., E.M., L.W., and G.B. contributed to the conception, design, and planning of the study; C.E. and G.G. contributed to the analysis of the data; C.E., P.B., E.M., C.V., and L.W. contributed to the acquisition of the data; C.E., G.G., L.W., and G.B. contributed to the interpretation of the results; G.G. and C.E. contributed to the drafting of the manuscript; and all authors contributed to critically reviewing or revising the manuscript for important intellectual content.

\section{Compliance with ethical standards}

All procedures performed in studies involving human participants were in accordance with the ethical standards of the national research committee and with the 1964 Helsinki declaration and its later amendments or comparable ethical standards.

Informed consent was obtained from all individual participants included in the study.

Conflict of interest G. Bos is C.E.O. CiMaas bv, Maastricht, The Netherlands. All other authors declare that they have no conflicts of interest.

Open Access This article is licensed under a Creative Commons Attribution 4.0 International License, which permits use, sharing, adaptation, distribution and reproduction in any medium or format, as long as you give appropriate credit to the original author(s) and the source, provide a link to the Creative Commons licence, and indicate if changes were made. The images or other third party material in this article are included in the article's Creative Commons licence, unless indicated otherwise in a credit line to the material. If material is not included in the article's Creative Commons licence and your intended use is not permitted by statutory regulation or exceeds the permitted use, you will need to obtain permission directly from the copyright holder. To view a copy of this licence, visit http://creativecommons.org/licenses/by/4.0/.

\section{References}

1. Luznik L, O'Donnell PV, Symons HJ, Chen AR, Leffell MS, Zahurak M, Gooley TA, Piantadosi S, Kaup M, Ambinder RF, Huff CA, Matsui W, Bolaños-Meade J, Borrello I, Powell JD, Harrington E, Warnock S, Flowers M, Brodsky RA, Sandmaier BM, Storb RF, Jones RJ, Fuchs EJ (2008) HLA-haploidentical bone marrow transplantation for hematologic malignancies using nonmyeloablative conditioning and high-dose, posttransplantation cyclophosphamide. Biol Blood Marrow Transplant 14(6):641-650

2. McCurdy SR, Kasamon YL, Kanakry CG, Bolanos-Meade J, Tsai HL, Showel MM et al (2017) Comparable composite endpoints after HLA-matched and HLA-haploidentical transplantation with post-transplantation cyclophosphamide. Haematologica. 102(2): 391-400

3. Sahebi F, Garderet L, Kanate AS, Eikema DJ, Knelange NS, Alvelo OFD, Koc Y, Blaise D, Bashir Q, Moraleda JM, Dreger P, Sanchez JF, Ciurea S, Schouten H, Shah NN, Verbeek M, Rösler W, DiezMartin JL, Schoenland S, D'Souza A, Kröger N, Hari P (2019) Outcomes of haploidentical transplantation in patients with relapsed multiple myeloma: an EBMT/CIBMTR report. Biol Blood Marrow Transplant 25(2):335-342

4. Castagna L, Mussetti A, Devillier R, Dominietto A, Marcatti M, Milone G, Maura F, de Philippis C, Bruno B, Furst S, Blaise D, Corradini P, Montefusco V (2017) Haploidentical allogeneic hematopoietic cell transplantation for multiple myeloma using posttransplantation cyclophosphamide graft-versus-host disease prophylaxis. Biol Blood Marrow Transplant 23(9):1549-1554

5. Chen Y, Lu J, Xu LP, Chen H, Zhang XH, Wang FR, Chen YH, Wang Y, Liu KY, Huang XJ (2018) Safety and efficacy of haploidentical stem cell transplantation for multiple myeloma. Bone Marrow Transplant 53(4):507-510

6. Ruggeri L, Capanni M, Urbani E, Perruccio K, Shlomchik WD, Tosti A et al (2002) Effectiveness of donor natural killer cell alloreactivity in mismatched hematopoietic transplants. Science (New York, NY) 295(5562):2097-2100

7. Pende D, Marcenaro S, Falco M, Martini S, Bernardo ME, Montagna D, Romeo E, Cognet C, Martinetti M, Maccario R, Mingari MC, Vivier E, Moretta L, Locatelli F, Moretta A (2009) Anti-leukemia activity of alloreactive NK cells in KIR ligandmismatched haploidentical HSCT for pediatric patients: evaluation of the functional role of activating KIR and redefinition of inhibitory KIR specificity. Blood. 113(13):3119-3129

8. Giebel S, Locatelli F, Lamparelli T, Velardi A, Davies S, Frumento G, Maccario R, Bonetti F, Wojnar J, Martinetti M, Frassoni F, Giorgiani G, Bacigalupo A, Holowiecki J (2003) Survival advantage with KIR ligand incompatibility in hematopoietic stem cell transplantation from unrelated donors. Blood. 102(3):814-819

9. Wanquet A, Bramanti S, Harbi S, Furst S, Legrand F, Faucher C et al (2018) Killer cell immunoglobulin-like receptor-ligand mismatch in donor versus recipient direction provides better graftversus-tumor effect in patients with hematologic malignancies undergoing allogeneic $\mathrm{T}$ cell-replete haploidentical transplantation followed by post-transplant cyclophosphamide. Biol Blood Marrow Transplant 24(3):549-554 
10. Bastos-Oreiro M, Anguita J, Martinez-Laperche C, Fernandez L, Buces E, Navarro A et al (2016) Inhibitory killer cell immunoglobulin-like receptor (iKIR) mismatches improve survival after T-cell-repleted haploidentical transplantation. Eur J Haematol 96(5):483-491

11. Willem C, Makanga DR, Guillaume T, Maniangou B, Legrand N, Gagne K, Peterlin P, Garnier A, Béné MC, Cesbron A, le Bourgeois A, Chevallier P, Retière C (2019) Impact of KIR/HLA incompatibilities on NK cell reconstitution and clinical outcome after T cellreplete haploidentical hematopoietic stem cell transplantation with posttransplant cyclophosphamide. J Immunol 202(7):2141-2152

12. Russo A, Oliveira G, Berglund S, Greco R, Gambacorta V, Cieri N, Toffalori C, Zito L, Lorentino F, Piemontese S, Morelli M, Giglio F, Assanelli A, Stanghellini MTL, Bonini C, Peccatori J, Ciceri F, Luznik L, Vago L (2018) NK cell recovery after haploidentical HSCT with posttransplant cyclophosphamide: dynamics and clinical implications. Blood. 131(2):247-262

13. Cooley S, McCullar V, Wangen R, Bergemann TL, Spellman S, Weisdorf DJ, Miller JS (2005) KIR reconstitution is altered by T cells in the graft and correlates with clinical outcomes after unrelated donor transplantation. Blood. 106(13):4370-4376

14. Osterborg A, Nilsson B, Bjorkholm M, Holm G, Mellstedt H (1990) Natural killer cell activity in monoclonal gammopathies: relation to disease activity. Eur J Haematol 45(3):153-157

15. Frohn C, Hoppner M, Schlenke P, Kirchner H, Koritke P, Luhm J (2002) Anti-myeloma activity of natural killer lymphocytes. Br J Haematol 119(3):660-664

16. El-Sherbiny YM, Meade JL, Holmes TD, McGonagle D, Mackie SL, Morgan AW et al (2007) The requirement for DNAM-1, NKG2D, and NKp46 in the natural killer cell-mediated killing of myeloma cells. Cancer Res 67(18):8444-8449

17. Carbone E, Neri P, Mesuraca M, Fulciniti MT, Otsuki T, Pende D, Groh V, Spies T, Pollio G, Cosman D, Catalano L, Tassone P, Rotoli B, Venuta S (2005) HLA class I, NKG2D, and natural cytotoxicity receptors regulate multiple myeloma cell recognition by natural killer cells. Blood. 105(1):251-258

18. Campbell KS, Cohen AD, Pazina T (2018) Mechanisms of NK cell activation and clinical activity of the therapeutic SLAMF7 antibody, elotuzumab in multiple myeloma. Front Immunol 9:2551

19. Giuliani M, Janji B, Berchem G (2017) Activation of NK cells and disruption of PD-L1/PD-1 axis: two different ways for lenalidomide to block myeloma progression. Oncotarget. 8(14):24031-24044

20. Sarkar S, Germeraad WT, Rouschop KM, Steeghs EM, van Gelder M, Bos GM et al (2013) Hypoxia induced impairment of NK cell cytotoxicity against multiple myeloma can be overcome by IL-2 activation of the NK cells. PLoS One 8(5):e64835

21. Sarkar S, Noort W, van Elssen C, Groen R, van Bloois L, van Gelder M, Schouten H, Tilanus M, Germeraad W, Wieten L, Martens A, Bos G (2015) Alloreactive Natural Killer cells have anti-tumor capacity against disseminated human multiple myeloma in Rag2-/- $\gamma \mathrm{C}$-/-mice when combined with low dose cyclophosphamide and total body irradiation. HSAO J Clin Immunol Immunother 2:008

22. Shi J, Tricot G, Szmania S, Rosen N, Garg TK, Malaviarachchi PA, Moreno A, DuPont B, Hsu KC, Baxter-Lowe LA, Cottler-Fox M, Shaughnessy Jr JD, Barlogie B, van Rhee F (2008) Infusion of haplo-identical killer immunoglobulin-like receptor ligand mismatched NK cells for relapsed myeloma in the setting of autologous stem cell transplantation. Br J Haematol 143(5):641-653

23. Kroger N, Shaw B, Iacobelli S, Zabelina T, Peggs K, Shimoni A, Nagler A, Binder T, Eiermann T, Madrigal A, Schwerdtfeger R, Kiehl M, Sayer HG, Beyer J, Bornhauser M, Ayuk F, Zander AR, Marks DI, the Clinical Trial Committee of the British Society of Blood and Marrow Transplantation and the German Cooperative Transplant Group (2005) Comparison between antithymocyte globulin and alemtuzumab and the possible impact of KIR-ligand mismatch after dose-reduced conditioning and unrelated stem cell transplantation in patients with multiple myeloma. Br J Haematol 129(5):631-643

24. Kumar S, Paiva B, Anderson KC, Durie B, Landgren O, Moreau P, Munshi N, Lonial S, Bladé J, Mateos MV, Dimopoulos M, Kastritis E, Boccadoro M, Orlowski R, Goldschmidt H, Spencer A, Hou J, Chng WJ, Usmani SZ, Zamagni E, Shimizu K, Jagannath S, Johnsen HE, Terpos E, Reiman A, Kyle RA, Sonneveld P, Richardson PG, McCarthy P, Ludwig H, Chen W, Cavo M, Harousseau JL, Lentzsch S, Hillengass J, Palumbo A, Orfao A, Rajkumar SV, Miguel JS, Avet-Loiseau H (2016) International Myeloma Working Group consensus criteria for response and minimal residual disease assessment in multiple myeloma. Lancet Oncol 17(8):e328-ee46

25. Nagler A, Dholaria B, Labopin M, Savani BN, Angelucci E, Koc Y et al (2020) Bone marrow versus mobilized peripheral blood stem cell graft in T-cell-replete haploidentical transplantation in acute lymphoblastic leukemia. Leukemia 34:2766-2775

26. Ruggeri A, Labopin M, Bacigalupo A, Gulbas Z, Koc Y, Blaise D et al (2018) Bone marrow versus mobilized peripheral blood stem cells in haploidentical transplants using posttransplantation cyclophosphamide. Cancer. 124(7):1428-1437

27. Ciurea SO, Schafer JR, Bassett R, Denman CJ, Cao K, Willis D, Rondon G, Chen J, Soebbing D, Kaur I, Gulbis A, Ahmed S, Rezvani K, Shpall EJ, Lee DA, Champlin RE (2017) Phase 1 clinical trial using mbIL21 ex vivo-expanded donor-derived NK cells after haploidentical transplantation. Blood. 130(16):1857-1868

28. van Hall T, Andre P, Horowitz A, Ruan DF, Borst L, Zerbib R et al (2019) Monalizumab: inhibiting the novel immune checkpoint NKG2A. J Immunother Cancer 7(1):263

Publisher's note Springer Nature remains neutral with regard to jurisdictional claims in published maps and institutional affiliations. 